\title{
Nursing Students' Experiences of Violence: A Questionnaire Survey
}

\author{
Öğrenci Hemşirelerin Şiddet Deneyimleri: Anket Çalışması
}

\author{
Neslihan KESER ÖZCAN, ${ }^{1}$ Hülya BİLGİN, ${ }^{2}$ Zeliha TÜLEK, ${ }^{3}$ Nur Elçin BOYACIOĞLU ${ }^{1}$
}

\begin{abstract}
Objectives: The purpose of this study was to identify the nature of violence experienced by nursing students, both in their private lives and during their work in clinical practice. In addition, we assessed factors that contributed to violence occurring during clinical practice.
\end{abstract}

Methods: A questionnaire was administered to 1200 nursing students and used to collect personal characteristics of students and their experience with violence.

Results: Results showed that student nurses were exposed to multiple types of violence during their private and professional life. Students most commonly experienced verbal aggression. Verbal and physical assaults that occurred during clinical practice were mostly from patients and their relatives. Following an assault, nursing students experienced emotional difficulties including anger, fear, and anxiety. In addition, students felt unsafe working at psychiatric clinics. Furthermore, students who were abused in their private life also reported greater exposure to violence during clinical practice.

Conclusion: The current findings show that student nurses are often exposed to violence and urgent preventions are needed. With this in mind, violence management and coping strategies should be included in the nursing curriculum.

Keywords: Aggression; assault; clinical practice; nursing; student nurse; violence.

\section{Introduction}

Workplace violence has major implications for staff safety, health and safety legislation, staff morale, sickness and absenteeism, recruitment and retention of high quality staff, and financial costs. ${ }^{[1-5]}$ There are a variety of contributing factors to workplace violence including patient/relative-related causes, organizational factors, healthcare staff issues, and societal fac-

${ }^{1}$ Department of Midwifery, Istanbul University Faculty of Health Science, Istanbul;

2Department of Psychiatric Nursing, Istanbul University Florence Nightingale Nursing Faculty, Istanbul;

${ }^{3}$ Department of Medicine Nursing, Istanbul University Florence Nightingale Nursing Faculty, Istanbul

Correspondence: Neslihan KESER ÖZCAN, M.D.

e-mail: neslihan_keser@hotmail.com

Psikiyatri Hemşireliği Dergisi 2014;5(1):49-56

Journal of Psychiatric Nursing 2014;5(1):49-56

Doi: $10.5505 /$ phd.2014.91886

Submitted: June 19, 2013 Accepted: March 08, 2014

\section{$\ddot{z z}$}

Amaç: Bu çalışmada, hemşirelik öğrencilerinin özel yaşamlarında ve klinik uygulamalar sırasında maruz kaldıkları şiddetin doğasını araştırmak amaçlanmıştır. Ayrıca, klinik uygulamalar sırasında meydana gelen şiddete katkıda bulunan faktörler de incelenmiştir.

Gereç ve Yöntem: Bin 200 hemşirelik öğrencisinin kişisel özellikleri ve şiddetle ilgili deneyimleri hakkında bilgi toplamak amacıyla bir anket formu kullanılmıstir.

Bulgular: Hemşirelik öğrencilerinin hem özel yaşamlarında, hem de klinik uygulamalar sırasında farklı şiddet türlerine maruz kaldıkları belirlenmiştir. Öğrenciler en fazla sözel agresyona maruz kalırken, klinik uygulamalarda görülen sözel ve fiziksel saldırıların çoğunlukla hastalar ve yakınları tarafından gerçekleştiği görülmüştür. Hemşirelik öğrencileri saldırılar sonrası öfke, korku ve anksiyete gibi emosyonel güçlükler yaşadıklarını belirtmiştir. Ayrıca, öğrencilerin psikiyatri kliniklerinde çalışıken kendilerini güvende hissetmedikleri belirlenmiştir. Özel yaşamlarında kötüye kullanıma maruz kalan öğrencilerin, klinik uygulamalar sırasında da şiddete daha fazla maruz kaldıkları saptanmıştır.

Sonuç: Bu çalışma sonuçları, hemşirelik öğrencilerinin şiddete çoğunlukla maruz kaldıklarını ve acil önlemler alınmasının gerekli olduğunu göstermektedir. şiddet yönetimi ve baş etme stratejileri, hemşirelik müfredatına dahil edilmelidir.

Anahtar sözcükler: Agresyon; saldırı; klinik uygulama; hemşirelik; öğrenci hemşireler; siddet.

tors. ${ }^{[2,4,6,7]}$ In a recent literature review, Hahn et al. ${ }^{[8]}$ showed that nurses are at a particularly high risk for workplace violence. Although violence towards nurses has been previously studied, little information is known about the specific experiences of nursing students. In fact, nursing students were not included enough in sampling population. ${ }^{[9]}$

One of the basic elements of an organization's strategy for preventing and addressing workplace violence is education and training. ${ }^{[6,10]}$ Self-protection training and pro-active management of aggression and violence are mostly aimed at post-registration staff rather than students. ${ }^{[1,11]}$ However, when the content of training programs and courses is considered, it is apparent that nursing students also need to learn about these topics (i.e. recognition of violent behaviour, assailant, skills required to deal with violence. ${ }^{[10,12,13]}$

In fact, data show that across all healthcare professions and levels, student nurses are at risk of being victims of a work-related violent incident. ${ }^{[1,6,11,14-16]}$ Beech $^{[11]}$ also states that this increased risk for students exists across all categories 
of violence ranging from verbal abuse to major assault. In addition, numerous studies report that nursing students, younger nurses, and less experienced and less educated nursing staff are more vulnerable to patient aggression..$^{[1,5,6,14,17-22]}$ There is a changing trend in workplace violence, such that co-worker, physician, and academic staff-initiated violence has increased in healthcare professions. In a study examining horizontal violence (an act of subtle or overt aggression perpetrated by one colleague towards another colleague), Randle ${ }^{[23]}$ claimed that the cycle of horizontal violence begins during nursing education. Therefore, regardless of rank or position, student nurses are exposed to several types of violence within their work environment.

Nau et al. ${ }^{[15]}$ noted that nursing students are well prepared to deal with a patient's emotions; however, they are often ill prepared for handling aggressive behaviours. Student nurses frequently see themselves as having little or no power while in the role of a student, even though they may be exposed to aggressive behaviour from a variety sources (i.e. patient, visitors, healthcare staff, and educators). The inability to address aggression may cause or exacerbate a student's negative view of the profession. ${ }^{[9]}$ Understanding the experiences of nursing students in response to violence is important because their clinical placement experience will influence their choices for postgraduate employment. ${ }^{[24,25]}$

In today's healthcare environment, there is an increasing awareness for zero tolerance policies regarding aggression and violence. However, at the same time aggression is seen as an inevitable problem of the profession, and there is a tendency to view aggression and violence as part of the job. Subsequently, healthcare-related violence is a complex problem, and the experience of student nurses plays a criticial role in the continuum of health care.

Therefore, the purpose of this study was to identify the degree of violence experienced by nursing students in their private and professional lives. Specifically, we assessed categories of violence and contributing factors to the violence that occurred during clinical practice.

\section{Materials and Methods}

\section{Design}

This research project used a cross-sectional descriptive survey design, which was implemented between January to March, 2010.

\section{Sample}

This study was conducted with students trained at five nursing colleges from different universities in Istanbul. All first, second, third, and fourth year nursing students were invited to participate in this study (first year students were included at the end of the semester, after completing their first clinical session). After gaining permission from school administrative boards, we approached students during lecture time and explained the aims of our study. A total of 1380 questionnaires were distributed and 1200 surveys (86.95\% response rate) were completed and returned during class time.

\section{Instrument}

Surveys were conducted in the Turkish language and took approximately 15-20 minutes to complete. Researchers prepared the questions based on a literature review, and the survey contained two sections: 1) personal characteristic questions (i.e. student age, gender, class) and 2) questions about violent experiences in a student's private life and during his/ her clinical practice. Violence was separated into four categories, and participants were asked to answer questions according to each type of violence, how often the violence occurred, and who initiated the violence. Students were provided with the following definitions for each category:

(1) Verbal aggression: Words/gestures that are threatening, humiliating, repulsive or frightening, and/or being yelled or shouted at.

(2) Physical violence: Hitting, pushing, kicking, scratching, spitting, hair pulling, slapping, beating, and/or being attacked with an object or attack to property.

(3) Verbal-sexual aggression: Words, tips, glances, and gestures with sexual content

(4) Physical-sexual harrassment: Touching private places on the body of someone else without permission. ${ }^{[26]}$

The factor loads of their competence to identify aggression/violence were evaluated; the nursing students were found to be competent (the factor loads for private life:.36.57 , cronbach's alpha .78; for clinical practice: .51-.82, cronbach's alpha .83).

\section{Ethical Considerations}

Administrative boards of relevant schools provided study approval and gave permission as an internal review board. Issues regarding participant confidentiality and agreement of participation were verbally explained and verbal informed consent was obtained from all subjects. Participants were guaranteed that there would be no consequences for nonparticipation should they choose to decline participation at any stage of data collection. Participants' rights, dignity, and well-being were protected throughout the study. Following data collection, students were given information regarding counselling in case they felt traumatized from the study; however, no participants expressed a need for this option.

\section{Data Analysis}

The Statistical Package for the Social Sciences (SPSS, 
v.15) analysed the data. Descriptive statistics (frequency, percentage) were used for the distribution of personal characteristics and the violent experiences of participants. Spearman's tests were also used to identify significant correlations between variables.

\section{Results}

\section{Participant Profile}

The mean age of participants was 21.17 years $(\mathrm{SD}=1.95)$ and females made up the majority of subjects (94.1\%, $\mathrm{n}=1127)$. The largest proportion of nursing students $(34.1 \%$, $\mathrm{n}=408$ ) were in their second year of school, followed by third $(25.4 \%, n=304)$, fourth $(23.6 \%, n=283)$, and first year students $(16.9 \%, \mathrm{n}=203)$.

\section{Exposure to Violence}

\section{Private Life}

Table 1 shows violent experiences reported by students in their private life. Participants most frequently experienced verbal aggression $(64.4 \%, \mathrm{n}=767)$ in their personal life.

\section{Clinical Practice}

The most frequently experienced type of aggression and violence during clinical practice was verbal aggression (61.2\%, $\mathrm{n}=728)$, followed by verbal-sexual aggression $(15.9 \%, \mathrm{n}=189)$, and physical violence $(8.6 \%, \mathrm{n}=102)$. Physical-sexual harassment were least reported among students $(5.2 \%, n=62)$. Regardless of the category, patients were found to be the most common perpetrator for all types of violence in clinical areas, followed by a patient's relatives (Table 2).

\section{Reported Reasons For Violence}

In response to the question, "why do patients exhibit violent behaviours in clinical settings?", students stated several reasons including, "poor environmental situations (crowding, noise, long waiting time, etc.; $71.4 \%, \mathrm{n}=852$ ), "the belief of being misunderstood" (63.8\%, $\mathrm{n}=761)$, and "unmet expectations" $(60.8 \%, \mathrm{n}=725)$.

When students were asked, "why do health care staff exhibit violent behaviours to you during clinical practice?" the most common responses were "lacking empathy skills" (76.5\%, $n=914)$, "intense work pressure" $(61.7 \%, n=737)$, and "demonstration of the power" $(60.4 \%, \mathrm{n}=721)$.
In regards to a lecturer's violent behaviours, the most common responses obtained were "demonstration of the power" $(66.5 \%, n=795)$, "lacking empathy skills" $(63 \%, n=753)$, and "being impatient" (37.2\%, $\mathrm{n}=445)$.

\section{Consequences of Violence}

Over half of the students $(53.2 \%, n=378)$ stated that they did not report the violent behaviour they experienced during clinical practice. They also noted that if they were to report, they preferred to contact a lecturer $(33.9 \%, \mathrm{n}=241)$.

Table 3 shows student reactions following violent behaviours experienced during clinical practice. Regardless of the assailant's identity, students most commonly felt "anger". After assault originating from patient and healthcare staff, students reported, "unwillingness to clinical practice", it means that they did not want to continue with clinical practice. Similarly, students experienced "estrangement to profession" following an assault from lecturers. Anxiety, lack of confidence, fear, and shame were the most common reported emotional reactions.

Although 47.1\% ( $\mathrm{n}=561$ ) of students did not feel safe in clinical settings, students rated pediatric $(36 \%, \mathrm{n}=427)$ and gynaecologic and obstetrical $(30.1 \%, n=357)$ clinics as the safest places. Psychiatric clinics were rated as the least safe place for students $(3 \%, n=36)$.

\section{Contributing Factors to Violence Experience in Clinical Practice}

Results showed that class level was related to certain types of violent behaviours. As students progressed in the program, the frequency of verbal, verbal-sexual aggression, and physical-sexual harassment increased (verbal $\mathrm{r}=.158, \mathrm{p}=.000$; physical $\mathrm{r}=.009, \mathrm{p}=.0765$; verbal-sexual $\mathrm{r}=.0168, \mathrm{p}=.000$; physicalsexual $\mathrm{r}=.058, \mathrm{p}=.045$ ). In contrast, neither a student's gender nor age was significantly related to violence experienced during clinical practice.

The relationship between violent situations in both private and clinical settings was separately examined for each category of violence. Although there was no significant relationship between physical violence and physical-sexual harrassment experiences during clinical practices and verbal aggression in private life, the relation with same direction was

Table 1. Distributions of being exposure to aggression and violence in private life of student nurses

\begin{tabular}{|c|c|c|c|c|c|c|c|c|}
\hline & \multicolumn{2}{|c|}{ Verbal } & \multicolumn{2}{|c|}{ Physical } & \multicolumn{2}{|c|}{ Verbal-sexual } & \multicolumn{2}{|c|}{ Physical-sexua } \\
\hline & n & $\%$ & n & $\%$ & $\mathbf{n}$ & $\%$ & $\mathrm{n}$ & $\%$ \\
\hline Exposure in private life & 767 & 64.4 & 294 & 24.7 & 525 & 44.1 & 182 & 15.3 \\
\hline Rarely & 399 & 33.5 & 214 & 18 & 294 & 24.7 & 146 & 12.3 \\
\hline Sometimes & 297 & 24.9 & 67 & 5.6 & 166 & 13.9 & 29 & 2.4 \\
\hline Often & 71 & 6.0 & 13 & 1.1 & 65 & 5.4 & 7 & 0.6 \\
\hline
\end{tabular}


Table 2. Types and sources of aggression and violence experienced by students during clinical practices

\begin{tabular}{|c|c|c|c|c|c|c|c|c|}
\hline \multirow{2}{*}{$\begin{array}{l}\text { Type } \\
\text { Source }\end{array}$} & \multicolumn{2}{|c|}{ Verbal } & \multicolumn{2}{|c|}{ Physical } & \multicolumn{2}{|c|}{ Verbal-sexual } & \multicolumn{2}{|c|}{ Physical-sexua } \\
\hline & $\mathrm{n}$ & $\%$ & $\mathrm{n}$ & $\%$ & $\mathrm{n}$ & $\%$ & $\mathrm{n}$ & $\%$ \\
\hline \multicolumn{9}{|l|}{ Patient } \\
\hline Rarely & 340 & 28.6 & 55 & 4.6 & 98 & 8.2 & 38 & 3.2 \\
\hline Sometimes & 105 & 8.8 & 9 & 0.8 & 16 & 1.3 & 2 & 0.2 \\
\hline Often & 27 & 2.3 & 2 & 0.2 & 8 & 0.7 & 2 & 0.2 \\
\hline Total & 472 & 39.7 & 66 & 5.6 & 122 & 10.2 & 42 & 3.6 \\
\hline \multicolumn{9}{|c|}{ Relatives of patient } \\
\hline Rarely & 257 & 21.6 & 32 & 2.7 & 57 & 4.8 & 6 & 0.5 \\
\hline Sometimes & 111 & 9.3 & 7 & 0.6 & 19 & 1.6 & 4 & 0.3 \\
\hline Often & 31 & 2.6 & 3 & 0.3 & 8 & 0.7 & 1 & 0.1 \\
\hline Total & 399 & 33.5 & 42 & 3.6 & 84 & 7.1 & 11 & 0.9 \\
\hline \multicolumn{9}{|l|}{ Lecturer } \\
\hline Rarely & 161 & 13.5 & 8 & 0.7 & 10 & 0.8 & 10 & 0.9 \\
\hline Sometimes & 99 & 8.3 & 5 & 0.4 & 2 & 0.2 & 0 & 0 \\
\hline Often & 52 & 4.3 & 2 & 0.2 & 1 & 0.1 & 0 & 0 \\
\hline Total & 312 & 26.1 & 15 & 1.3 & 13 & 1.1 & 10 & 0.9 \\
\hline \multicolumn{9}{|l|}{ Nurses } \\
\hline Rarely & 207 & 17.4 & 7 & 0.6 & 6 & 0.5 & 4 & 0.3 \\
\hline Sometimes & 110 & 9.2 & 3 & 0.3 & 3 & 0.3 & 0 & 0 \\
\hline Often & 45 & 3.8 & 3 & 0.3 & 2 & 0.2 & 2 & 0.2 \\
\hline Total & 362 & 30.4 & 13 & 1.1 & 11 & 1 & 6 & 0.5 \\
\hline \multicolumn{9}{|l|}{ Doctors } \\
\hline Rarely & 157 & 13.2 & 7 & 0.6 & 41 & 3.4 & 7 & 0.6 \\
\hline Sometimes & 63 & 5.3 & 1 & 0.1 & 9 & 0.8 & 1 & 0.1 \\
\hline Often & 15 & 1.3 & 3 & 0.3 & 6 & 0.5 & 3 & 0.3 \\
\hline Total & 235 & 19.8 & 11 & 1 & 56 & 4.7 & 11 & 1 \\
\hline \multicolumn{9}{|l|}{ Other staff } \\
\hline Rarely & 89 & 7.5 & 6 & 0.5 & 26 & 2.2 & 5 & 0.4 \\
\hline Sometimes & 40 & 3.4 & 3 & 0.3 & 8 & 0.7 & 3 & 0.3 \\
\hline Often & 8 & 0.7 & 1 & 0.1 & 3 & 0.3 & 0 & 0 \\
\hline Total & 137 & 11.6 & 10 & 0.9 & 37 & 3.1 & 8 & 0.7 \\
\hline
\end{tabular}

Table 3. The consequences of violent behaviours experienced by student nurses during clinical practices

\begin{tabular}{|c|c|c|c|c|c|c|}
\hline \multirow{2}{*}{$\begin{array}{l}\text { Sources } \\
\text { Consequences }\end{array}$} & \multicolumn{2}{|c|}{ Patient } & \multicolumn{2}{|c|}{ Health care staff } & \multicolumn{2}{|c|}{ Lecturer } \\
\hline & $\%$ & $\mathrm{n}$ & $\mathrm{n}$ & $\%$ & $\mathrm{n}$ & $\%$ \\
\hline Anger & 58.2 & 355 & 60.8 & 285 & 61.4 & 197 \\
\hline Fear & 19 & 116 & 10.4 & 49 & 24.1 & 77 \\
\hline Shame & 18.5 & 113 & 12.8 & 60 & 24.4 & 78 \\
\hline Anxiety & 27 & 165 & 21.7 & 102 & 35.6 & 114 \\
\hline Powerlessness & 12 & 73 & 10 & 47 & 16.6 & 53 \\
\hline Apaty & 17 & 104 & 14.7 & 69 & 19.4 & 62 \\
\hline Helplessness & 10.7 & 65 & 8.1 & 38 & 16.3 & 52 \\
\hline Depression & 7.5 & 46 & 5.8 & 27 & 15.9 & 51 \\
\hline Self-blame & 13 & 79 & 8.3 & 39 & 15.9 & 51 \\
\hline The lack of confidence & 25.4 & 155 & 22.6 & 106 & 36.9 & 118 \\
\hline Unwillingness to clinical practice & 35.8 & 218 & 35.6 & 167 & 54.5 & 175 \\
\hline Estrangement to profession & 34.1 & 208 & 35.6 & 167 & 58.4 & 187 \\
\hline Disturbed social relations & 14.1 & 86 & 15.6 & 73 & 15.9 & 51 \\
\hline Somatic complaints & 6.2 & 38 & 6 & 28 & 7.5 & 24 \\
\hline
\end{tabular}

found amongst other type of violence (Table 4).

As presented in Table 5, students who were exposed to any type of violence in clinical setting were also subjected to another types of violence (Table 5).

\section{Discussion}

\section{Exposure to Violence}

Our finding that students most commonly faced verbal aggression in their private life was consistent with previous 
Table 4. The relationship between kind of aggression and violence experienced by student nurses both in private life and clinical practice

\begin{tabular}{|c|c|c|c|c|}
\hline Private & Verbal & Physical & Verbal-sexual & Physical-sexual \\
\hline Clinical & & $r$ & $r$ & $r$ \\
\hline Verbal & $.219^{* *}$ & $.120^{* *}$ & $.114^{* *}$ & $.059^{*}$ \\
\hline Physical & .055 & $.096^{* *}$ & $.091^{* *}$ & $.150^{* *}$ \\
\hline Verbal-sexual & $.061^{*}$ & $.081^{* *}$ & $.262^{* *}$ & $.177^{* *}$ \\
\hline Physical-sexual & .005 & $.082^{* *}$ & $.071^{*}$ & $.157^{* *}$ \\
\hline
\end{tabular}

Table 5. The interrelationship between kinds of aggression and violence experienced in clinical settings

\begin{tabular}{lccc}
\hline & Physical & Verbal-sexual & Physical-sexual \\
\hline Verbal & $.193^{* *}$ & $.201^{* *}$ & $.140^{* *}$ \\
Physical & & $.360^{* *}$ & $.482^{* *}$ \\
Verbal-sexual & & & $.457^{* *}$ \\
\hline${ }^{* *}: p<0.01$ spearman correlation. & & &
\end{tabular}

reports. A study by Celik and Bayraktar ${ }^{[18]}$ found that nursing students reported the rate of verbal aggression as $100 \%$, followed by sexual $(53.3 \%)$ and physical (5.7\%) violence in their personal life. In addition, our results showing that student nurses experienced high exposure rates to all type of violence are consistent with the literature.

Regarding work-related violence, it is clear that verbal aggression is commonly displayed in clinical environments, and students are frequently subjected to these behaviours. Indeed, our finding that approximately $60 \%$ of students experience this type of violence compliments earlier research. Student reports of verbal aggression in clinical settings range from $35-92 \%$. $^{[14,27-29]}$

In addition, the gap observed between verbal aggression and other categories of violence in the current study is similar to previous results. For example, Celebioglu et al. ${ }^{[29]}$ recently reported that verbal aggression rates were $91.6 \%$ according to student nurses in Turkey; however, physical-sexual harrassment rates were approximately $8 \%$ in this same population. Similarly, Hinchberger ${ }^{[9]}$ found that verbal aggression was $69 \%$ and physical violence was only 10\% among student nurses in the USA. In a recent study with a group of nursing students in Iran, ${ }^{[22]}$ the rate of physical assault to students was $6.7 \%$, similar to our findings (9\%). Joint reports of "workplace violence in healthcare" by WHO, ILO ve $\mathrm{ICN}^{[26]}$ further support these trends and declare that $27-67 \%$ of healthcare staff from various countries are exposed to verbal agression, while only $3-17 \%$ experience physical violence. ${ }^{[30]}$

Importantly, our results are consistent with the average nursing student's experience in Turkey. In a systematic review of violence towards healthcare workers in Turkey, ${ }^{[31]}$ the rate of verbal aggression is reported at $46.7 \%-100 \%$, the rate of physical violence at $1.8 \%-52.5 \%$, and the rate of sexual violence at $1.1 \%-73 \%$. Moreover, research emphasizes that nurses are at the greatest risk for work-place violence. In studies conducted with medical students, a group similar to nursing students in Turkey, Acik et al. ${ }^{[32]}$ found that verbal aggression was reported by $65 \%$ of students and physical violence reported by $33 \%$, while Aydın et al. ${ }^{[33]}$ reported verbal aggression rates at $88.3 \%$ and physical violence at $2.9 \%$. Although these are similar findings, the reported rates differ depending on participants and type of violence. Subsequently, it shoud be noted that studies on workplace violence in healthcare settings may differ in the definition and content of violent behaviours, as well as the sampled groups. Therefore, specific results may be restricted to an individual study.

The current results show that various perpetrators were detected according to violence category, which means that the identity of an assailant may vary depending on the type of violence. While patients and their relatives have been the primary perpetrators in studies investigating verbal aggression and physical violence, ${ }^{[14,18,29,34]}$ healthcare workers are reported as perpetrators in studies evaluating psychological and sexual violence. ${ }^{[9,29,35]}$ McKenna et al. ${ }^{[36]}$ noted that patients were the primary perpetrators of verbal and verbal-sexual aggression; however, Hinchberger ${ }^{[9]}$ reported that clinical staff was the most assailant group to students, as they were associated with approximately $50 \%$ of violence. The current results show that in addition to patient and relative aggression, nurses were perpetrators of verbal aggression and physical violence, and doctors were perpetrators of sexual violence. Celik and Bayrak- 
$\operatorname{tar}^{[18]}$ also reported that $33.8 \%$ of students were subjected to verbal aggression from nursing staff and $31.6 \%$ of students were subjected to same type of violence from doctors. In addition, patients and their relatives provided the most common sources of sexual violence. ${ }^{[18]}$ Taken together, these data illustrate types of abuse that student nurses experience in clinical settings.

\section{Reported Reasons of Violence}

Patient and relative-related violence most commonly originates from poor environmental conditions and difficulties within the healthcare system. ${ }^{[37,38]}$ These reasons are within an external model that demonstrates environmental effects on the incidence of aggressive events. ${ }^{[39]}$ In our study, the reason for patient-initiated violent behaviours was the belief that patient's were being misunderstood. This explanation is dynamically similar to lacking empathy, which was the reported reason for violent behaviours from the healthcare staff. The current results also found intense work pressure and demonstration of power as reasons for healthcare staff to exert violent behaviours. In a study by Thomas and Burk, ${ }^{[40]}$ students noted that nursing staff exhibited violent behaviors as a result of work load.

It is interesting that nursing staff that were targets of violent behaviours in clinical settings behaved similarly towards nursing students. Moreover, studies show that former victims choose inexperienced staff or student nurses as the new victims. ${ }^{[27,40,41]}$ Thomas and Burk $^{[40]}$ pointed out that nurses placed at the bottom of the hierarchical structure have feelings of powerlessness and believe they do not receive enough support from their managers. This feeling of powerlessness then causes them to become a perpetrator of violent behaviour towards more powerless and inexperienced people (i.e. student nurses). Student nurses claim that nursing staff treats them with an insulting, sarcastic, impolite, and disrespectful manner, traits that may be used to exhibit violent behaviours. ${ }^{[40]}$ In a qualitative analysis conducted by Lash et al. ${ }^{[27]}$ the authors argued that most students were victims of verbal aggression, and the most common perpetrators were clinical staff nurses. McKenna et al. ${ }^{[41]}$ also mention that experienced nurses display psychological violence towards beginners.

Lack of empathy and demonstration of power, which were mentioned as causes of violence from lecturers, are similar explanations to those from other health care staff. Impatience experienced by the powerlessness and stress load of lecturers (lecturers working in our sample schools were not the regular staff working in clinics, yet they were responsible for guide students in clinical settings) was reflected to students having a negative attitude. Impatience may not differ from the dynamics of intensive work pressure and lack of empathy, and it appears that all three traits contributed to staff violence on nursing students. Lash et al. ${ }^{[27]}$ noted that student nurses believed that their lecturers were not accepted in clinics, which may provide another reason of students' violence experiences.

\section{Consequences of Violence}

In the current study, the basic emotional responses experienced by students after a violent incident were anger, anxiety, lack of confidence, fear, and shame. These responses are commonly found in the literature. ${ }^{[18,34,41-43]}$ Unwillingness to continue in clinical practice and becoming disheartened to the profession are the most frequent responses following nurse and lecturer-initiated violent interactions, respectively. ${ }^{[18]}$

Many studies report that healthcare staff, including students, is exposed to more violent behaviours from patients and relatives in psychiatric clinics. ${ }^{[14,41,44-46]}$ The current results confirm these findings, as student nurses' ranked psychiatric clinics as the least safe place for clinical practice. However, in a study investigating horizontal violence in the first professional year, McKenna et al. ${ }^{[41]}$ found lower rates of horizontal violence in psychiatric clinics compared to other clinics. Therefore, although healthcare staff may feel unsafe in psychiatric clinics, these areas are not as affected by horizontal violence.

\section{Contributing Factors to Violence Experiences in Clinical Practices}

The results of this study that class progression was associated with increased violence corresponds to Celik and Bayraktar's ${ }^{[18]}$ results. This relationship is not surprising because as students advance in their education, they experience more clinical practice.

We also found a relationship between violence exposure in one's private life and violent experiences during clinical practice. This finding is supported by Little's work ${ }^{[20]}$ about nurses' violence victimization. Revictimization studies examine the rates by which individuals in the general population who were abused as children sustain some form of abuse as adults. Little ${ }^{[20]}$ suggests that child abuse may put a person at risk for sustained violence in the workplace. Vahip ${ }^{[4]}$ also states that childhood abuse may produce vulnerability for exposure to violence. Unfortunately, detailed research in this area is lacking, and there are no comparison data exist as mentioned by Little. ${ }^{[20]}$ Although we did not assess evidence for childhood abuse in the current study, our results showing a relationship between private and work-related exposure to violence offer support for the revictimization theory.

\section{Conclusion}

Our findings emphasize that student nurses are exposed to different categories of violence in their private life and in clinical settings. Students most frequently experienced verbal aggression, and patients and their relatives were the primary 
sources of assaults occurring during clinical practice. The most common reasons for violence were poor environmental conditions and problematic relationship styles. Following an assault, students experienced anger, fear, and anxiety. Students also rated psychiatric clinics as the least safe work environment. In addition, the results showed that students abused during their private life were more likely to be exposed to violence during clinical practice.

Although the academic staff exhibited aggression towards nursing students, the severity of this relationship remains unclear. Regardless, this study provides evidence that academic and clinical staff members display violence towards their coworkers, and our findings suggest that healthcare leaders and administrators should take measures to ensure the safety of nursing students in clinical settings. Consequently, violence management should be added to the nursing curriculum.

Further studies required to examine how student nurses perceive the workplace violence. Qualitative studies based on individual lived experiences are recommended to investigate other related variables with violence and the nature of violence. The findings of previous experiences of violence in students'personal lifes are needed to investigate again in different samples. Detailed research according to each type of violence sources (patient/ relatives of patient, doctor, nurse, other staff and lecturer) of causes are suggested.

Conflict decrease/ prevention training are developed for both nurses and students. This training should be based on developing empathy skills and therapeutic communication usage and risk managemet, deescalation techniques. Nevertheless, the institution will receive managertal and structural measures to prevent violence in clinic, are the most important.

\section{Limitations}

It should be noted that research investigating sensitive issues, such as exposure to violence, is difficult because reporting violent experiences can be traumatic for subjects. Due to the lack of immediate reports and legal regulations, retrospective studies are commonly used to assess violent experiences. Therefore, it is possible that participants may have prejudices related to past experiences, which may lead them to bias their answers on the survey.

Even though the heterogeneity of the data is a strength, there are some concerns. The cultural differences among the students might have influenced perceptions of the detailed information provided about violent behaviors in the questionaire.

\section{References}

1. Beech $B$, Leather P. Evaluating a management of aggression unit for student nurses. J Adv Nurs 2003;44:603-12.
2. Farrell GA, Bobrowski C, Bobrowski P. Scoping workplace aggression in nursing: findings from an Australian study. J Adv Nurs 2006;55:778-87.

3. Grenyer BF, Ilkiw-Lavalle O, Biro P, Middleby-Clements J, et al. Safer at work: development and evaluation of an aggression and violence minimization program. Aust N Z J Psychiatry 2004;38:804-10.

4. Hesketh KL, Duncan SM, Estabrooks CA, Reimer MA, et al. Workplace violence in Alberta and British Columbia hospitals. Health Policy 2003;63:311 21.

5. Winstanley S, Whittington R. Aggression towards health care staff in a UK general hospital: variation among professions and departments. J Clin Nurs 2004;13:3-10.

6. Beech B, Leather P. Workplace violence in the health care sector: A review of staff training and integration of training evaluation models. Aggression and Violent Behavior 2006;11:27-43.

7. Child RJ, Mentes JC. Violence against women: the phenomenon of workplace violence against nurses. Issues Ment Health Nurs 2010;31:89-95.

8. Hahn S, Zeller A, Needham I, Kok G, et al. Patient and visitor violence in general hospitals: A systematic review of the literature. Aggression and Violent Behavior 2008;13:431-41.

9. Hinchberger PA. Violence against female student nurses in the workplace. Nurs Forum 2009;44:37-46.

10. Oostrom JK, van Mierlo H. An evaluation of an aggression management training program to cope with workplace violence in the healthcare sector. Res Nurs Health 2008;31:320-8.

11. Beech B. Sign of the times or the shape of things to come? A 3-day unit of instruction on 'aggression and violence in health settings for all students during pre-registration nurse training'. Accid Emerg Nurs 2001;9:204-11.

12. Farrell G, Cubit K. Nurses under threat: a comparison of content of 28 aggression management programs. Int J Ment Health Nurs 2005;14:44-53.

13. Irwin A. The nurse's role in the management of aggression. J Psychiatr Ment Health Nurs 2006;13:309-18.

14. Ferns T, Meerabeau L. Verbal abuse experienced by nursing students. J Adv Nurs 2008;61:436-44.

15. Nau J, Dassen T, Halfens R, Needham I. Nursing students' experiences in managing patient aggression. Nurse Educ Today 2007;27:933-46.

16. Nau J, Halfens R, Needham I, Dassen T. The De-Escalating Aggressive Behaviour Scale: development and psychometric testing. J Adv Nurs 2009;65:1956-64.

17. Beech B. Aggression prevention training for student nurses: differential responses to training and the interaction between theory and practice. Nurse Educ Pract 2008;8:94-102.

18. Celik SS, Bayraktar N. A study of nursing student abuse in Turkey. J Nurs Educ 2004;43:330-6.

19. Echternacht MR. Potential for violence toward psychiatric nursing students: risk reduction techniques. J Psychosoc Nurs Ment Health Serv 1999;37:36-9.

20. Little L. Risk factors for assaults on nursing staff: childhood abuse and education level. J Nurs Adm 1999;29:22-9.

21. Rippon TJ. Aggression and violence in health care professions. J Adv Nurs 2000;31:452-60.

22. Aghajanloo A, Nirumand-Zandi K, Safavi-Bayat Z, Alavi-Majd H. Clinical violence in nursing students. Iran J Nurs Midwifery Res 2011;16:284-7.

23. Randle J. Bullying in the nursing profession. J Adv Nurs 2003;43:395-401.

24. Curtis J, Bowen I, Reid A. You have no credibility: nursing students' experiences of horizontal violence. Nurse Educ Pract 2007;7:156-63.

25. Nolan PW, Chung MC. Nursing students' perceptions of their first mental health placement. Nurse Educ Today 1999;19:122-8.

26. Di Martino V. Workplace violence in the health sector - Country case studies Brazil, Bulgaria, Lebanon, Portugal, South Africa, Thailand, plus an additional Australian study: Synthesis Report. Geneva: ILO/ICN/WHO/PSI Joint Programme on Workplace Violence in the Health Sector; 2002.

27. Lash AA, Kulakaç O, Buldukoglu K, Kukulu K. Verbal abuse of nursing and 
midwifery students in clinical settings in Turkey. J Nurs Educ 2006;45:396403.

28. Longo J. Horizontal violence among nursing students. Arch Psychiatr Nurs 2007;21:177-8.

29. Celebioğlu A, Akpinar RB, Küçükoğlu S, Engin R. Violence experienced by Turkish nursing students in clinical settings: their emotions and behaviors. Nurse Educ Today 2010;30:687-91.

30. Chen WC, Hwu HG, Kung SM, Chiu HJ, Wang JD. Prevalence and determinants of workplace violence of health care workers in a psychiatric hospital in Taiwan. J Occup Health 2008;50:288-93.

31. Özcan NK, Bilgin H. Türkiye'de sağlık çalışanlarına yönelik şiddet: Sistematik derleme. Türkiye Klinikleri Tıp Bilimleri Dergisi 2011;31:1442-56.

32. Acik Y, Deveci SE, Gunes G, Gulbayrak C, et al. Experience of workplace violence during medical speciality training in Turkey. Occup Med (Lond) 2008;58:361-6.

33. Aydın N, Coşkun F, Balcı Ö, Turan H, et al. The evaluation of their job and working medium by research asisstants in Faculty of Medicine of Gaziantep. Syndrome 2007;19:71-4.

34. Kisa S. Turkish nurses' experiences of verbal abuse at work. Arch Psychiatr Nurs 2008;22:200-7.

35. Bronner G, Peretz C, Ehrenfeld M. Sexual harassment of nurses and nursing students. J Adv Nurs 2003;42:637-44.

36. McKenna BG, Poole SJ, Smith NA, Coverdale JH, et al. A survey of threats and violent behaviour by patients against registered nurses in their first year of practice. Int J Ment Health Nurs 2003;12:56-63.

37. Ayranci U, Yenilmez C, Balci Y, Kaptanoglu C. Identification of violence in
Turkish health care settings. J Interpers Violence 2006;21:276-96.

38. Uzun O. Perceptions and experiences of nurses in Turkey about verbal abuse in clinical settings. J Nurs Scholarsh 2003;35:81-5.

39. Duxbury J, Whittington R. Causes and management of patient aggression and violence: staff and patient perspectives. J Adv Nurs 2005;50:469-78.

40. Thomas SP, Burk R. Junior nursing students' experiences of vertical violence during clinical rotations. Nurs Outlook 2009;57:226-31.

41. McKenna BG, Smith NA, Poole SJ, Coverdale JH. Horizontal violence: experiences of Registered Nurses in their first year of practice. J Adv Nurs 2003;42:90-6.

42. Needham I, Abderhalden C, Halfens RJ, Fischer JE, et al. Non-somatic effects of patient aggression on nurses: a systematic review. J Adv Nurs 2005;49:283-96.

43. Uzun O, Bag B, Ozer N. Impact on nurses of verbal abuse in the workplace. Journal of Nursing College of Atatürk University 2001;4:42-7.

44. Gudjonsson GH, Rabe-Hesketh S, Szmukler G. Management of psychiatric in-patient violence: patient ethnicity and use of medication, restraint and seclusion. Br J Psychiatry 2004;184:258-62.

45. Nolan P, Dallender J, Soares J, Thomsen S, et al. Violence in mental health care: the experiences of mental health nurses and psychiatrists. J Adv Nurs 1999;30:934-41.

46. Waddell AE, Katz MR, Lofchy J, Bradley J. A pilot survey of patient-initiated assaults on medical students during clinical clerkship. Acad Psychiatry 2005;29:350-3.

47. Vahip I. Domestic violence and its developmental dimension: a different perspective. Turk Psikiyatri Derg 2002;13:312-9. 